\title{
Biochar influences nitrogen availability in Andisols of north Idaho forests
}

\author{
Shan Shan ${ }^{1,2} \mathbb{D} \cdot$ Mark D. Coleman $^{1}$
}

Received: 19 November 2019 / Accepted: 1 February 2020 / Published online: 7 February 2020

(c) Springer Nature Switzerland AG 2020

\begin{abstract}
Biochar application in forest soils can influence tree growth and forest productivity through mediating plant-available nitrogen $(\mathrm{N})$ pools. However, how soil $\mathrm{N}$ availability and related transformations respond to biochar addition in cold-temperate forest ecosystems is not well understood. Our study assessed the effect of a hardwood forest residue biochar on soils taken from an elevational gradient within a cold-temperate, north Idaho forest. Forest soils were incubated at $0 \%$, $10 \%$ and $20 \%$ biochar amendments in a greenhouse for 120 days. We measured soil small organic $\mathrm{N}$ (amino compound) and inorganic $\mathrm{N}$ (ammonium and nitrate) pools, enzyme activities, small organic $\mathrm{N}$ turnover, $\mathrm{N}$ mineralization and nitrification rates. Biochar decreased small organic $\mathrm{N}$ and inorganic $\mathrm{N}$ concentrations in most elevations. Enzyme analysis shows biochar increased the activity of aminopeptidase, but decreased the activity of $N$-acetyl- $\beta$-D-glucosaminidase, $\beta$-glucosidase and acid phosphatase. Biochar did not influence small organic $\mathrm{N}$ turnover and $\mathrm{N}$ mineralization rates, but decreased nitrification rate. In conclusion, hardwood forest residue biochar application in cold-temperate forests has important impact on short-term soil $\mathrm{N}$ cycling.
\end{abstract}

Keywords Biochar · Nitrogen cycling · Forest soils · Extracellular enzymes

\section{Introduction}

The production of biochar from forest biomass and use of biochar as a soil amendment have caused wide interests in forest management as a method to reduce fire hazard and increase carbon (C) sequestration [1-3]. Biochar is enriched with $C$ that is stable for decades to centuries. Consequently it has the potential to sequester $C$ and mitigate global warming as a soil amendment [4-6]. However, there is concern that application of biochar can influence soil fertility and consequently the plant growth. Biochar's effect on soil health and plant production has been intensively studied in agricultural ecosystem, whereas representations of forest, especially natural forest ecosystems, are lacking [7-11]. The few studies with controversial findings of soil nitrogen $(\mathrm{N})$ mineralization response to biochar, as well as the general lack of knowledge in biochar effect overtime limit our understanding of the consequences in soil nutrient cycling following biochar application in forest ecosystems [12].

Conifer forests are naturally N-limited [13, 14]. Although there is often abundant $\mathrm{N}$ in forest soils, most soil $\mathrm{N}$ is in insoluble organic polymer forms that are not readily available for plant and microbes to utilize. Soil $\mathrm{N}$ can only be taken up by plants and microbes as small molecules, such as amino compounds, ammonium $\left(\mathrm{NH}_{4}{ }^{+}\right)$and nitrate $\left(\mathrm{NO}_{3}{ }^{-}\right)$[15]. The formation of these plant-available $\mathrm{N}$ compounds involves depolymerization of complex organic

Electronic supplementary material The online version of this article (https://doi.org/10.1007/s42452-020-2156-y) contains supplementary material, which is available to authorized users.

Shan Shan, shans@miamioh.edu| ${ }^{2}$ College of Natural Resources, University of Idaho, Moscow, ID 83844, USA. ${ }^{2}$ Present Address: Department of Biology, Miami University, Oxford, OH 45056, USA. 
$\mathrm{N}$ and subsequent $\mathrm{N}$ mineralization. Depolymerization controls the degradation of large organic $\mathrm{N}$ polymers into amino compounds and other organic monomers. Depolymerization is mediated by a variety of microbial extracellular enzymes. Amino compounds are subsequently transformed into $\mathrm{NH}_{4}{ }^{+}$and $\mathrm{NO}_{3}{ }^{-}$via $\mathrm{N}$ mineralization. Both depolymerization and $\mathrm{N}$ mineralization are important soil $\mathrm{N}$ transformation processes that determine soil $\mathrm{N}$ availability. When studying the $\mathrm{N}$ availability for plant growth in an ecosystem, inorganic $\mathrm{N}$ forms, $\mathrm{NH}_{4}{ }^{+}$and $\mathrm{NO}_{3}{ }^{-}$, are traditionally considered as the major plant $\mathrm{N}$ sources, while the importance of amino compounds is constantly ignored. Study of the impact of environmental factors on $\mathrm{N}$ availability has been focused on $\mathrm{N}$ mineralization, while depolymerization has received much less attention [15]. More recent studies emphasize the importance of amino compounds in plant $\mathrm{N}$ nutrient supply in cold-temperate and arctic ecosystems [16-18]. For example, the importance of amino compounds as a plant and microbial $\mathrm{N}$ source increases as the elevation increases in northern Idaho conifer forests [19]. The exclusion of amino compounds and depolymerization from measurements can cause underestimation of plant-available $\mathrm{N}$ and incomplete understanding of environmental effect on soil nutrient.

Soil $\mathrm{N}$ transformations are influenced by charcoal, which is a native component of fire-adapted forest ecosystems like temperate and boreal conifer forests [20-22]. Given the prospect of adding biochar, which is analogous to fire-derived charcoal, to N-limited conifer forest ecosystems, it is important to understand biochar's impacts on forest soils. Biochar incorporation into the soil can increase soil cation and anion exchange capacity, $\mathrm{pH}$ and waterholding capacity [23-26]. These modifications in soil physiochemical environment can alter $\mathrm{N}$ cycling processes. In neutral to slight alkaline soils, the soil pH generally favors nitrifiers; and raising the $\mathrm{pH}$ of acid forest soils has been found to stimulate nitrification rates $[27,28]$, whereas higher anion exchange capacity can lead to less $\mathrm{N}$ leaching loss in the form of nitrate [29]. Furthermore, the residue oils associated with biochar can be used as an energy source for soil decomposers and consequently increase microbial priming of soil organic matter and the release of nutrients during organic matter decomposition [30-32]. A few past studies reported a short-term increase in $\mathrm{N}$ mineralization following biochar addition [33-35]. However, inconsistent findings are also reported in other studies [23, 36-39]. Similarly, biochar effect on extracellular enzymes involved in depolymerization varies with studies [40-45]. It is commonly found that the impact of biochar application is strongly dependent on soil types $[46,47]$, but the mechanisms driving various biochar effects on soil nutrient cycling across soil types remain unknown. Studies of biochar degradation show that high content of soil organic matter can stimulate the release of labile $C$ from biochar pores $[48,49]$. If biochar does increase soil microbial priming of soil organic matter, high soil organic matter content can potentially exert positive feedbacks on this biochar effect. We suggest that the accumulation of organic matter and climatic conditions could be important factors controlling biochar-soil interactions.

Biochar's effect on plant-available $\mathrm{N}$ pools and soil $\mathrm{N}$ cycling has been intensively studied in agriculture systems, but is less well understood in forest ecosystems [50]. Field study of biochar application on tree growth is also rare, and the implications of biochar effect on short- and longterm forest productivity remain inconclusive with various results from different studies [9]. We used a greenhouse incubation study to further our understanding of biochar's influence on forest soil $\mathrm{N}$ availability and transformation processes. Fine-textured Andisols were selected to represent a common soil type across the cold-temperate forest region of north Idaho. Andisols were selected from an elevational gradient with similar andic soil properties, but varying climatic condition and initial soil organic matter content: increasing soil organic matter content with elevation [19]. Andisols are a very unique soil type with physiochemical and mineralogical properties that are fundamentally different from other soil orders. They are widely distributed in the Pacific Northwest of USA from low to high elevations, covering large areas of agricultural and forest ecosystems [51, 52]. We hypothesized that biochar alters soil $\mathrm{N}$ cycling mainly through introducing labile $\mathrm{C}$ which promotes soil microbial decomposition activity. Based on previous discussion, higher soil organic matter content would stimulate biochar effect by driving the labile $\mathrm{C}$ input into the soil from biochar. We predicted that biochar addition increases organic $\mathrm{N}$ decomposition and $\mathrm{N}$ mineralization rates, and that this positive effect increases with elevation as soil organic matter content increases.

\section{Materials and methods}

\subsection{Soil and biochar}

Soils used for greenhouse incubation were sampled from mature forest stands at three different elevations in the St Joe and Clearwater National Forests of northern Idaho (Table 1). Each stand had a closed canopy with few understory shrubs. Surface soils were formed from Mt. Mazama volcanic ash, with a subsurface parent material of loess or metamorphic geologic origin. Soil textures were silt loam with $<10 \%$ coarse fraction. Soils were collected in late summer by removing the organic horizon and excavating soil from the $A$ and $B_{w}$ horizon to $10 \mathrm{~cm}$ depth. Three random locations at each sampling site were used to 
Table 1 Site characteristics of three elevation (low, middle and high) andic forest soils

\begin{tabular}{lllccc}
\hline Elevation $(\mathrm{m})$ & Soil type & Dominate tree species & $\begin{array}{l}\text { Stand age } \\
\text { (years) }\end{array}$ & MAT $\left({ }^{\circ} \mathrm{C}\right)$ & MAP $(\mathrm{mm})$ \\
\hline Low 925 & Alfic Udivitrands & Abies grandis & 103 & 7.2 & 766 \\
Middle 1436 & Typic Udivitrands & Abies grandis & 90 & 4.3 & 1002 \\
High 1852 & Typic Haplocryands & Tsuga mertensiana & 170 & 2.3 & 1057 \\
\hline
\end{tabular}

$M A T$ mean annual temperature, MAP mean annual precipitation collect approximately $0.02 \mathrm{~m}^{3}$ of bulk soils. The soils were passed through a 4-mm sieve to remove roots and any coarse fragments, then packed on ice and transported to the greenhouse for incubation setup. These soils showed increasing soil organic matter content and free amino compound concentration, and decreasing soil $\mathrm{pH}$ as elevation increased (Table 2). Representative soil physical and chemical data were obtained through site soil series identification [53] and from a parallel study [19]. Climate data were derived from thin-plate splines of weather data across the region as developed by Rehfeldt [54].

CQuest ${ }^{\text {TM }}$ biochar derived from hardwood forest residues was used for this experiment. CQuest ${ }^{\mathrm{TM}}$ biochar was produced from hardwood furniture mill residue in a fluidized bed fast pyrolysis reactor $\left(130\right.$ ton day ${ }^{-1}$ ) that was heated to $450-500^{\circ} \mathrm{C}$ (Dynamotive Energy Systems, West Lorne Bio Oil Co-Generation L.P. division, West Lorne, Ontario, Canada). Biochar chemical properties were 6.8 for $\mathrm{pH}, 30 \mathrm{cmol}^{+} \mathrm{kg}^{-1} \mathrm{CEC}, 620 \mathrm{mg} \mathrm{g}^{-1}$ total C, $4.5 \mathrm{mg} \mathrm{g}^{-1}$ total $\mathrm{N}, 3.3 \mathrm{mg} \mathrm{kg}^{-1} \mathrm{NH}_{4}{ }^{+},<1.6 \mathrm{mg} \mathrm{kg}^{-1} \mathrm{NO}_{3}{ }^{-}$and $\mathrm{NO}_{2}{ }^{-}$, and $0.40 \mathrm{~g} \mathrm{~cm}^{-3}$ bulk density. CQuest Biochar particle size distribution was $100 \%<2 \mathrm{~mm}, 95 \%<1 \mathrm{~mm}$ diameter and $60 \%<0.5 \mathrm{~mm}$.

\subsection{Greenhouse incubation}

Soil moisture content was obtained by drying a subsample to $75^{\circ} \mathrm{C}$ with a HB 43-S halogen moisture balance (Mettler Toledo Inc., Columbus, OH). Fresh soil was mixed with biochar to make $0 \%, 10 \%$ and $20 \%$ (dry weight percentage) biochar-soil mixtures. A total of $1500 \mathrm{~g}$ mixture was made for each percentage of biochar-soil mix and then evenly divided into five replicate seedling containers of $656 \mathrm{~cm}^{3}$ volume with drainage (D40, Stuewe \& Sons, Tangent, OR,
USA). Containers with biochar-soil mixtures were incubated for 115 or 120 days in the greenhouse of University of Idaho and were watered regularly to maintain the moisture content at near field capacity level.

\subsection{Harvest and soil extraction}

Soils were harvested in two batches first at 115 days and again at 120 days. Soils were passed through a 2-mm sieve before analysis for chemistry. Plant-available $\mathrm{N}$ forms (amino compounds, $\mathrm{NH}_{4}{ }^{+}$and $\mathrm{NO}_{3}{ }^{-}$) were extracted from fresh subsamples ( $10 \mathrm{~g}$ dry equivalent) with $40 \mathrm{~mL}$ of $2 \mathrm{M}$ $\mathrm{KCl}$ on an end-over-end shaker for $20 \mathrm{~min}$ followed by vacuum filtration. Extracts were stored at $-20^{\circ} \mathrm{C}$ prior analysis for total free amino compounds and $\mathrm{NH}_{4}{ }^{+}$and $\mathrm{NO}_{3}{ }^{-}$.

\subsection{Plant-available $\mathrm{N}$ pools}

Soil $\mathrm{NH}_{4}{ }^{+}$and $\mathrm{NO}_{3}{ }^{-}$concentrations were measured using an auto-analyzing system (FIAlab-2500 system, FIAlab Instruments Inc., Bellevue, WA, USA). Total free amino compounds were determined using an o-phthaldialdehyde (OPA) and $\beta$-mercaptoethanol (ME) method [55] adapted for high-throughput microplate assay. This method captures total free amino compounds in the form of both amino acids and amino sugars. Briefly, a working reagent was made by mixing $100 \mathrm{mg}$ OPA (Sigma, P0657), $200 \mu \mathrm{L}$ ME (Sigma, M6250) and $10 \mathrm{~mL}$ methanol (Sigma, 34860) with $400 \mathrm{~mL}$ of $0.02 \mathrm{M}$ borate buffer (pH 9.5). Then $200 \mu \mathrm{L}$ of working reagent and $50 \mu \mathrm{L}$ of soil extraction were added into four wells of a 96-well black microplate. Another four wells on the plate received $200 \mu \mathrm{L}$ borate buffer and soil extraction to serve as background control. The plate also contained a standard curve of glycine to be compared to

Table 2 Initial physical and chemical characteristics of the three elevation (low, middle and high) andic forest soils

\begin{tabular}{|c|c|c|c|c|c|c|c|c|c|}
\hline \multirow[t]{2}{*}{ Elevation } & \multirow{2}{*}{$\begin{array}{l}\text { Amino com- } \\
\text { pounds } \\
\left(\mathrm{mg} \mathrm{kg}^{-1}\right)\end{array}$} & \multirow[t]{2}{*}{$\mathrm{NH}_{4}^{+}\left(\mathrm{mg} \mathrm{kg}^{-1}\right)$} & \multirow[t]{2}{*}{$\mathrm{NO}_{3}^{-}\left(\mathrm{mg} \mathrm{kg}^{-1}\right)$} & \multicolumn{3}{|c|}{ Soil texture } & \multirow{2}{*}{$\begin{array}{l}\text { Bulk density } \\
\left(\mathrm{g} \mathrm{cm}^{-3}\right)\end{array}$} & \multicolumn{2}{|c|}{ Soil pH } \\
\hline & & & & Sand (\%) & Silt (\%) & Clay (\%) & & $\left(\mathrm{H}_{2} \mathrm{O}\right)$ & $(\mathrm{NaF})$ \\
\hline Low & 1.40 & 1.25 & 0.13 & 35 & 51 & 14 & 0.86 & 6.44 & 10.17 \\
\hline Middle & 2.29 & 1.95 & 0.33 & 35 & 52 & 13 & 0.75 & 5.01 & 11.11 \\
\hline High & 4.85 & 1.62 & 0.27 & 31 & 57 & 12 & 0.70 & 4.66 & 8.54 \\
\hline
\end{tabular}


the samples and a standard curve of $\mathrm{NH}_{4}^{+}$to correct for the $\mathrm{NH}_{4}{ }^{+}$interference in the sample. The plate was read at 360-nm excitation and 450-nm emission wavelengths on a Gen5 microplate reader (BioTek Instruments Inc., Winooski, VT, USA).

\subsection{Extracellular enzyme assay}

We measured two enzymes which catalyze the end reaction of protein depolymerization and control the release the amino compounds: alanine aminopeptidase (AAP) which represents the aminopeptidases that free single amino acids during protein degradation and $\mathrm{N}$-acetyl$\beta$-D-glucosaminidase (NAG) which releases glucosamine from chitin. We also measured other common enzymes which participate in depolymerization: the $C$ enzyme as $\beta$-glucosidase (BG) which frees glucose and the $P$ enzyme as acid phosphatase (AP) which frees phosphate from organic matter. Enzyme activity was measured using a fluorescent method [56]. Table 1 (supplementary material) lists all enzymes with the corresponding substrates and standards used. Soil slurries were prepared by mixing fresh soils ( $1 \mathrm{~g}$ dry equivalent) with $125 \mathrm{~mL} 50 \mathrm{mM}$ acetate buffer ( $\mathrm{pH}$ 5.5) in 200-mL polypropylene bottles and homogenized with a Brinkmann Polytron (Kinematica AG, Lucerne, Switzerland) for $1 \mathrm{~min}$. The slurries were then transferred to Pyrex (Corning, NY, USA) bowls and continuously stirred. Aliquots of slurry ( $200 \mu \mathrm{L}$ each) were transferred into 96 -well assay plates containing substrates and standards. The plates were then incubated in dark at $20^{\circ} \mathrm{C}$ for $2 \mathrm{~h}$ (NAG), $3 \mathrm{~h}$ (BG), $4 \mathrm{~h}$ (AP) or $6 \mathrm{~h}$ (AAP). After incubation, $\mathrm{NaOH}(1.0 \mathrm{M})$ was added to halt the reaction prior to reading fluorescence (360-nm excitation and 450-nm emission). Enzyme activity was obtained by correcting the fluorescence of sample for the background and quenched control, expressed in the unit of $\mathrm{nmol} \mathrm{g}^{-1} \mathrm{~h}^{-1}$ [57]. Including the quenched control in the calculation adjusts the assay for any interference that biochar may have on the substrate [41].

\section{6 $\mathrm{N}$ transformations}

Net $\mathrm{N}$ mineralization was measured with a 7-day laboratory incubation. A subsample of fresh soil ( $50 \mathrm{~g}$ dry equivalent) was weighed out in a polyethylene ziplock bag, with moisture adjusted to $60 \%$ of field capacity. Bags were then half sealed and incubated in darkness for 7 days. After incubation, soils were extracted to obtain inorganic $\mathrm{N}$ using procedures described previously. Net $\mathrm{N}$ mineralization rate was obtained by comparing the initial and after-incubation total inorganic $\mathrm{N}$ concentration. Net nitrification was the net changing rate of $\mathrm{NO}_{3}{ }^{-}$concentration during the 7-day incubation. To represent the turnover rate of small amino molecules, we calculated a turnover index by dividing the releasing rate of amino acids (AAP activity) and amino sugars (NAG activity) by total free amino compound concentration. Since the method we used to measure total free amino compounds measures both soil amino acids and amino sugars at the same time, the activity of AAP + NAG was used as the flux. This turnover index was based on the generation of a representative amino compounds normalized by the amount of total free amino acids in the form of glycine. As such, it is an index of small organic amino compound turnover rate for comparison among treatments.

\subsection{Soil $\mathrm{pH}$ and $\mathrm{C} / \mathrm{N}$ analysis}

Soil $\mathrm{pH}$ was measured in water $(1: 1)$ and in $\mathrm{NaF}$ (Accumet Basic AB15 pH meter, Fisher Scientific Inc., Beverly, MA, USA). Soil pH in NaF was obtained to assess the degree of andic soil mineral weathering and its potential impact on hydroxide ion release [58]. $\mathrm{NaF} \mathrm{pH}$ was measured after mixing $1 \mathrm{~g}$ soil with $50 \mathrm{~mL} \mathrm{NaF}$ solution $(1 \mathrm{M})$, continuously stirred for $2 \mathrm{~min}$. Soil total $\mathrm{C}$ and $\mathrm{N}$ were determined using a LECO TruSpec CN analyzer (LECO Corp., St. Joseph, MI, USA) after samples were oven-dried at $60^{\circ} \mathrm{C}$ and ground to pass a 60 -mesh screen.

\subsection{Data analysis}

A two-way factorial ANOVA was used to test the effect of elevation (three levels) and biochar percentage (three levels) on plant-available $\mathrm{N}$ pools, enzyme activities and log ratios, $\mathrm{N}$ transformation and soil characteristics. Statistical analyses were performed using PROC GLM in SAS (SAS, 2008). The models were checked for residual normality. Pairwise least square mean differences were obtained using Tukey's HSD test.

\section{Results}

\subsection{Soil elevation}

After the 4-month greenhouse incubation, the elevation of sampling sites was the main factor influencing soil chemistry. Soil pH decreased with elevation, while total N, C increased with elevation (Fig. 1a-c, Table 3). The C-to-N ratio increased with elevation only in soils without char addition; and the C-to-N ratio of soils with char addition was higher at low elevation than those at middle or high elevation (Fig. 1d, Table 3). Soil amino compounds and $\mathrm{NH}_{4}{ }^{+}$concentrations increased with elevation (Fig. 2a, b, Table 3). $\mathrm{NO}_{3}{ }^{-}$concentration of soils without char was similar between low and high elevations, but higher at middle 
$\mathbf{a}$

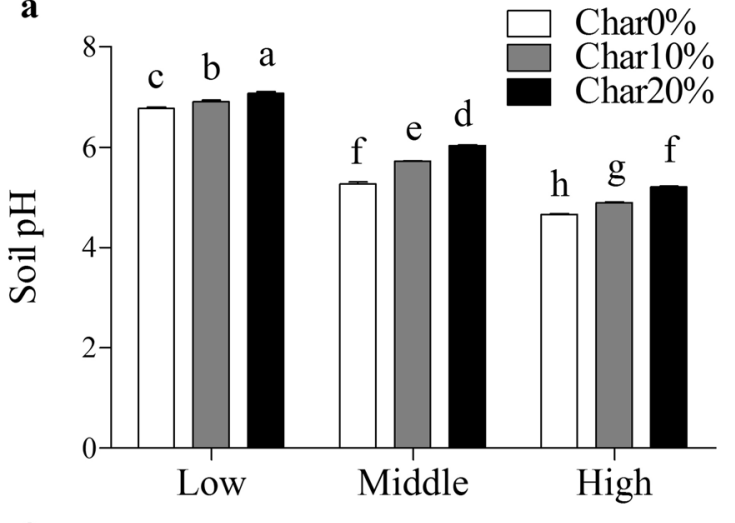

b

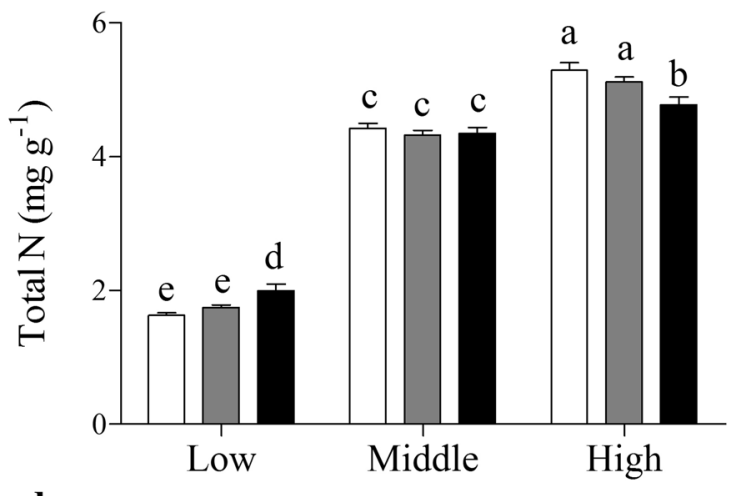

d

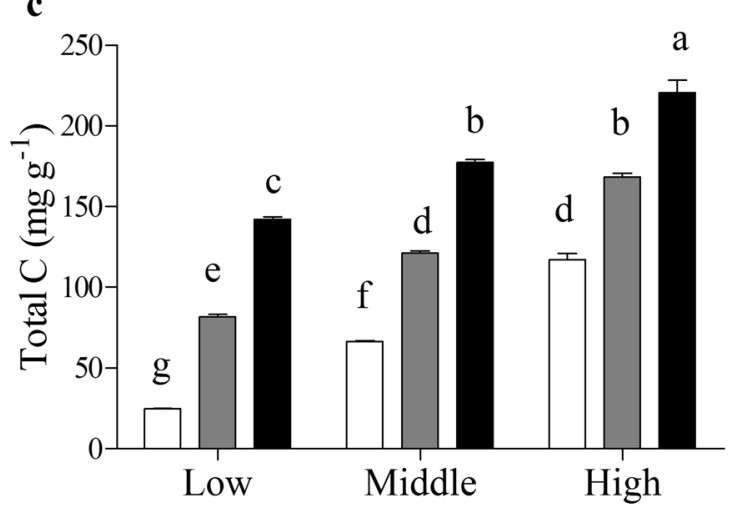

Fig. 1 Elevation and biochar effect on a soil $\mathrm{pH}$, b soil total $\mathrm{N}, \mathbf{c}$ soil total $\mathbf{C}$ and $\mathbf{d}$ soil $\mathrm{C}$-to- $\mathrm{N}$ ratio after incubation. Different letters within each frame indicate differences between treatments at the

elevation (Fig. 2c). $\mathrm{NO}_{3}{ }^{-}$concentration of char-added soils was similar at all elevations. The activity of AAP and BG varied with elevation, with the lowest values showed up in the middle-elevation soils (Fig. 3a, b). NAG on the contrary showed the highest activity in the middle-elevation soils (Fig. 3c). AP activity increased with elevation (Fig. 3d, Table 3). Amino compound turnover index decreased with elevation, whereas net $\mathrm{N}$ mineralization and net nitrification was not influenced by elevation (Fig. 4, Table 3).

\subsection{Biochar}

The effect of biochar on soil $\mathrm{pH}$, total $\mathrm{N}$ and $\mathrm{C}$-to- $\mathrm{N}$ ratio varied by elevation (elevation $\times$ biochar $P<0.001$, Table 3 ). Biochar increased soil pH by $0.3-0.7$, with the highest effect shown in middle-elevation soils (Fig. 1a). Biochar caused an increase in total $\mathrm{N}$ in low-elevation soils and a decrease in high-elevation soils (Fig. 1b). Biochar increased the C-to- $\mathrm{N}$ ratio of all soils, but the increase was almost fourfold in low-elevation soils, while it was only twofold in middle- and high-elevation soils, possibly due to the higher initial $\mathrm{C}$ content of the middle- and high-elevation soils (Fig. 1d).

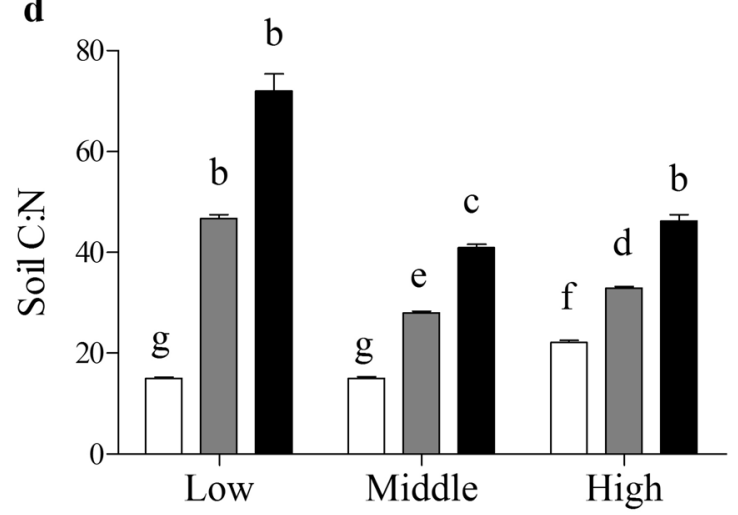

$P<0.05$ level. Low, middle and high represent three andic forest soils across an elevational gradient

Soil amino compound concentration decreased following biochar incubation ( $P<0.001$, Fig. $2 \mathrm{a})$, and this response did not vary with elevation (biochar $\times$ elevation interaction $P=0.160$, Table 3). Biochar decreased $\mathrm{NH}_{4}{ }^{+}$ and $\mathrm{NO}_{3}{ }^{-}$concentrations in middle- and high-elevation soils, but not in the low-elevation soils (Fig. 2b, c). Thus, the effect of biochar on $\mathrm{NH}_{4}{ }^{+}$and $\mathrm{NO}_{3}{ }^{-}$varied with elevation (biochar $\times$ elevation interaction $P<0.001$, Table 3 ).

Biochar addition increased AAP activity, but decreased $B G$ and NAG activities $(P<0.001$, Fig. $3 a-c)$. Biochar effect on AAP and NAG activities was consistent among elevations (biochar $\times$ elevation interaction $P>0.19$, Table 3). The effect of biochar on BG and AP activities varied by elevation (elevation $\times$ biochar interaction $P<0.02$, Table 3). Biochar decreased BG activity in low- and high-elevation soils, and decreased AP activity only in low-elevation soils (Fig. 3b, d).

No significant effect of biochar addition was found on amino compound turnover or net mineralization (Table 3, Fig. 4a, b). Biochar addition decreased net nitrification rate from positive to negative values in all elevation soils $(P<0.001$, Fig. 4 c). 
Table 3 Analysis of variance $P$ values for soil chemistry and enzyme activities

\begin{tabular}{|c|c|c|c|c|}
\hline & Soil pH & Total N & Total C & $\mathrm{C}-\mathrm{N}$ \\
\hline Elevation & $<0.001^{* * *}$ & $<0.001^{* * *}$ & $<0.001^{* * *}$ & $<0.001^{* * *}$ \\
\hline Biochar & $<0.001^{* * *}$ & 0.550 & $<0.001^{* * *}$ & $<0.001^{* * *}$ \\
\hline \multirow[t]{2}{*}{ Elevation $\times$ biochar } & $<0.001^{* * *}$ & $<0.001^{* * *}$ & $<0.297$ & $<0.001^{* * *}$ \\
\hline & \multicolumn{2}{|c|}{ Amino compounds } & $\mathrm{NH}_{4}^{+}$ & $\mathrm{NO}_{3}^{-}$ \\
\hline Elevation & \multicolumn{2}{|c|}{$<0.001^{* * *}$} & $<0.001^{* * *}$ & $<0.001^{* * *}$ \\
\hline Biochar & \multicolumn{2}{|c|}{$<0.001^{* * *}$} & $<0.001^{* * *}$ & $<0.001^{* * *}$ \\
\hline \multirow[t]{2}{*}{ Elevation $\times$ biochar } & \multicolumn{2}{|c|}{0.160} & $<0.001^{* * *}$ & $<0.001^{* * *}$ \\
\hline & AAP & BG & NAG & AP \\
\hline Elevation & $<0.001^{* * *}$ & $<0.001^{* * *}$ & $<0.001^{* * *}$ & $<0.001^{* * *}$ \\
\hline Biochar & $<0.001^{* * *}$ & $<0.001^{* * *}$ & $<0.001^{* * *}$ & 0.223 \\
\hline \multirow[t]{2}{*}{ Elevation $\times$ biochar } & 0.197 & $0.015^{*}$ & 0.370 & $0.010^{* *}$ \\
\hline & \multicolumn{2}{|c|}{ Amino compound turnover } & Net $\mathrm{N}$ mineralization & Net nitrification \\
\hline Elevation & \multicolumn{2}{|c|}{$<0.001^{* * *}$} & 0.057 & 0.581 \\
\hline Biochar & \multicolumn{2}{|c|}{0.285} & 0.452 & $<0.001^{* * *}$ \\
\hline \multirow[t]{2}{*}{ Elevation $\times$ biochar } & \multicolumn{2}{|c|}{0.157} & 0.431 & 0.721 \\
\hline & \multicolumn{2}{|c|}{ Ln AAP } & Ln NAG & Ln AP \\
\hline Elevation & \multicolumn{2}{|c|}{0.167} & $<0.001^{* * *}$ & $<0.001^{* * *}$ \\
\hline Biochar & \multicolumn{2}{|c|}{$0.002^{* *}$} & $<0.001^{* * *}$ & $0.014^{*}$ \\
\hline \multirow{2}{*}{$\begin{array}{l}\text { Elevation } \times \text { biochar } \\
\text { Ln BG }\end{array}$} & \multicolumn{2}{|c|}{0.056} & 0.401 & $<0.001^{* * *}$ \\
\hline & \multicolumn{2}{|c|}{0.966} & $<0.001^{* * *}$ & 0.984 \\
\hline
\end{tabular}

$A A P$ alanine aminopeptidase, $B G \beta$-glucosidase, NAG $N$-acetyl- $\beta$-D-glucosaminidase, $A P$ acid phosphatase

Significance levels: $<0.05\left({ }^{*}\right),<0.01\left(^{* *}\right),<0.001\left(^{* * *}\right)$

\section{Discussion}

Biochar addition decreased plant-available $\mathrm{N}$ pools in the fine-textured Andisols of northern Idaho mature forests ( $>80$ years). This decrease was most significant in forest soils of middle and high elevations (Fig. 2). Because soil amino compounds, $\mathrm{NO}_{3}{ }^{-}$and $\mathrm{NH}_{4}{ }^{+}$represent the major directly available $\mathrm{N}$ pools for plant growth, biochar addition could cause potential short-term $\mathrm{N}$ limitation in primary productivity. This result contrasts with the finding of a similar incubation study by Gao and Deluca [59], where biochar addition led to immediate increase in plant-available pool sizes in a cold-temperate forest. Distinct biochar effects between studies can be attributed by a few factors. First, Gao and Deluca used a microdialysis method which measures a slightly different portion of dissolved $\mathrm{N}$ than the traditional soil extraction method we used. Microdialysis captures the $\mathrm{N}$ in the diffusive flux [60], which could have responded differently to biochar than the extracted total N. Second, their incubation period was shorter ( 16 days compared to 3 months), allowing for the assessment of immediate soil chemistry response upon the addition of biochar. Longer-term field experiments have also reported positive biochar effect on $\mathrm{NH}_{4}{ }^{+}$, but not on $\mathrm{NO}_{3}{ }^{-}$[11], whereas negative biochar effect was also found on resin bag-trapped inorganic N [29]. More importantly, soil type remains an unknown factor regarding its contribution to biochar effects. Between the two studies, biochar's effect seems to contrast in two soil types (Inceptisols vs Andisols), which are similarly young, but have much different mineral origins [53]. Compared to Inceptisols, Andisols has a much higher water-holding capacity [61]; biochar addition could have resulted high soil water content and $\mathrm{N}$ loss through denitrification in Andisols [62].

Our finding of negative biochar effect on soil $\mathrm{N}$ availability in a forest ecosystem differs from a large quantity of agriculture studies where positive or neutral biochar effects on soil amino compounds, $\mathrm{NO}_{3}{ }^{-}$and $\mathrm{NH}_{4}{ }^{+}$concentrations are reported $[39,63,64]$. Forest and agricultural ecosystems are distinct in soil nutrient conditions, which could lead to different biochar impacts. Agricultural soils have high $\mathrm{N}$ availability and are usually enriched by fertilizer, which creates the potential for higher nitrate leaching loss compared to forests. Since biochar addition can increase soil cation exchange capacity and decrease leaching loss $[25,26]$, a larger $\mathrm{N}$ pool size along with a higher 


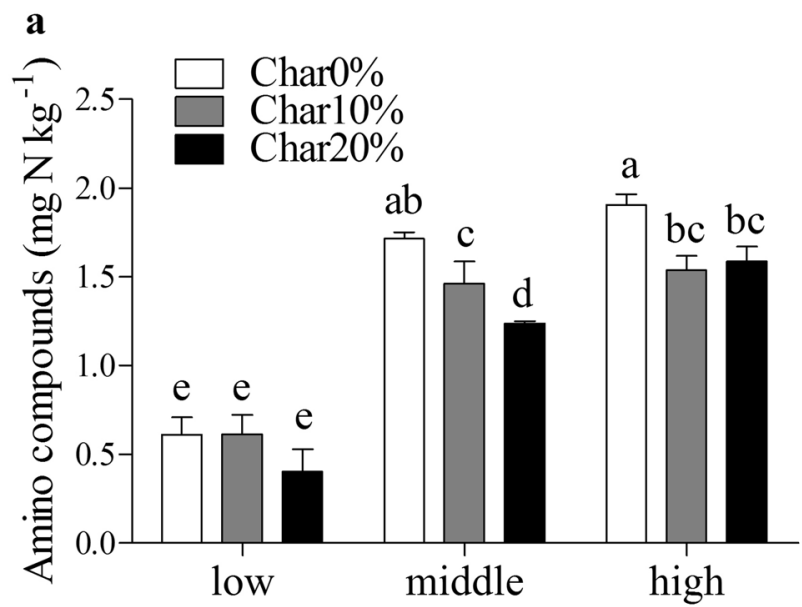

b

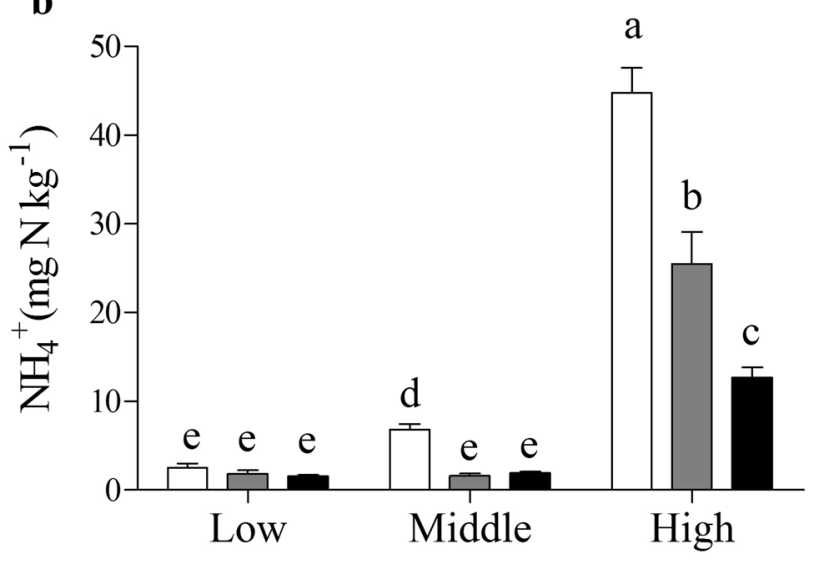

c

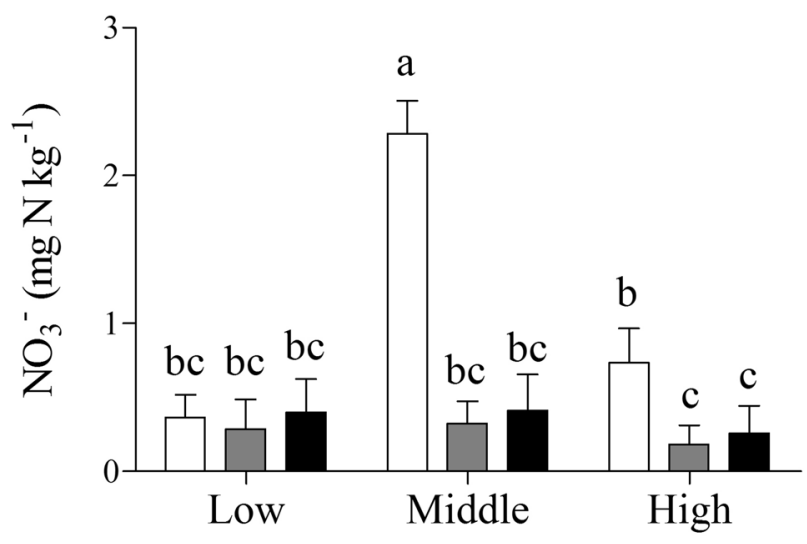

Fig. 2 Elevation and biochar effect on soil a amino compounds, b $\mathrm{NH}_{4}^{+}$and $\mathbf{c ~} \mathrm{NO}_{3}^{-}$after incubation. Different letters within each frame indicate differences between treatments at the $P<0.05$ level. Low, middle and high represent three andic forest soils across an elevational gradient

use efficiency of fertilizer has been reported following biochar amendment in agriculture soils [65]. Cold-temperate conifer forests in northwest United States, on the other hand, are usually less $\mathrm{N}$-enriched with little leaching loss $[13,14]$. The addition of biochar as a low-quality
C source could enhance microbial uptake for $\mathrm{N}$ [66] and further reduce plant-available $\mathrm{N}$ pool sizes in the soil. The varying effects of biochar on soil $\mathrm{N}$ in contrasting ecosystems suggest potentially different plant growth responses to biochar amendments in these ecosystems and call for careful extrapolation of biochar addition effect among different ecosystems.

Application rate could be an important factor regulating biochar's effects on soil N. Our study used much higher rates (10-20\%) of biochar application compared to other similar studies in cold-temperate forests (e.g., $2 \%$ in Gao and Deluca) $[11,59]$. Meta-analysis in agricultural ecosystems has shown that plant growth response to biochar is sensitive to application rate: below the application rate equivalent to $7.4 \%$, a majority of studies observed positive plant growth responses; as the application rate increased to $55 \%$, a larger portion of studies showed negative growth responses [64]. Similarly, plant uptake of $\mathrm{N}$ was also mostly suppressed at higher biochar application rates [67]. We are uncertain whether higher dosage of biochar prevents plants from using soil $\mathrm{N}$ and growth by reducing $\mathrm{N}$ availability. However, soil $\mathrm{N}$ responses should be sensitive to biochar application rate, because the latter is closely related to soil physiochemical properties which can affect $\mathrm{N}$ cycling $[67,68]$. Nevertheless, high-dosage biochar experiment is still underrepresented with limited amount of studies, and more observations are needed for a clear picture of biochar-soil interactions [69].

Biochar addition affected $\mathrm{N}$ demand and suppressed $\mathrm{C}$ demand in soil microorganisms. The enzyme AAP, which is produced by soil microorganisms for amino acid uptake during organic matter decomposition, showed higher activity with biochar addition. This higher enzyme activity indicates higher microbial allocation of resources toward the acquisition of N. However, the enzyme NAG, which also facilitates $\mathrm{N}$ acquisition in microbes, showed decreased activity in response to biochar addition. This increased AAP and decreased NAG in response to biochar have also been reported in other studies $[41,45]$. The distinct responses by two $\mathrm{N}$ enzymes could be caused by different interference mechanisms of biochar with the catalytic reaction process or product of the two enzymes. For instance, the raised soil $\mathrm{pH}$ by biochar could bring AAP closer toward its optimal reaction condition (optimal $\mathrm{pH} 7.5$ ), while shifting away from the optimal pH of NAG (4-5.5) [70]. It also suggests complicated biochar effects on the different processes in microbial growth and activity. The $\mathrm{N}$-containing products of these enzymes can be used for different processes of microbial growth after assimilated. Amino acids released by AAP can be used for protein construction, while glucosamine released by NAG can be used for cell wall synthesis [71]. Biochar could have stimulated microbial metabolic activities such as respiration while suppressing biomass 

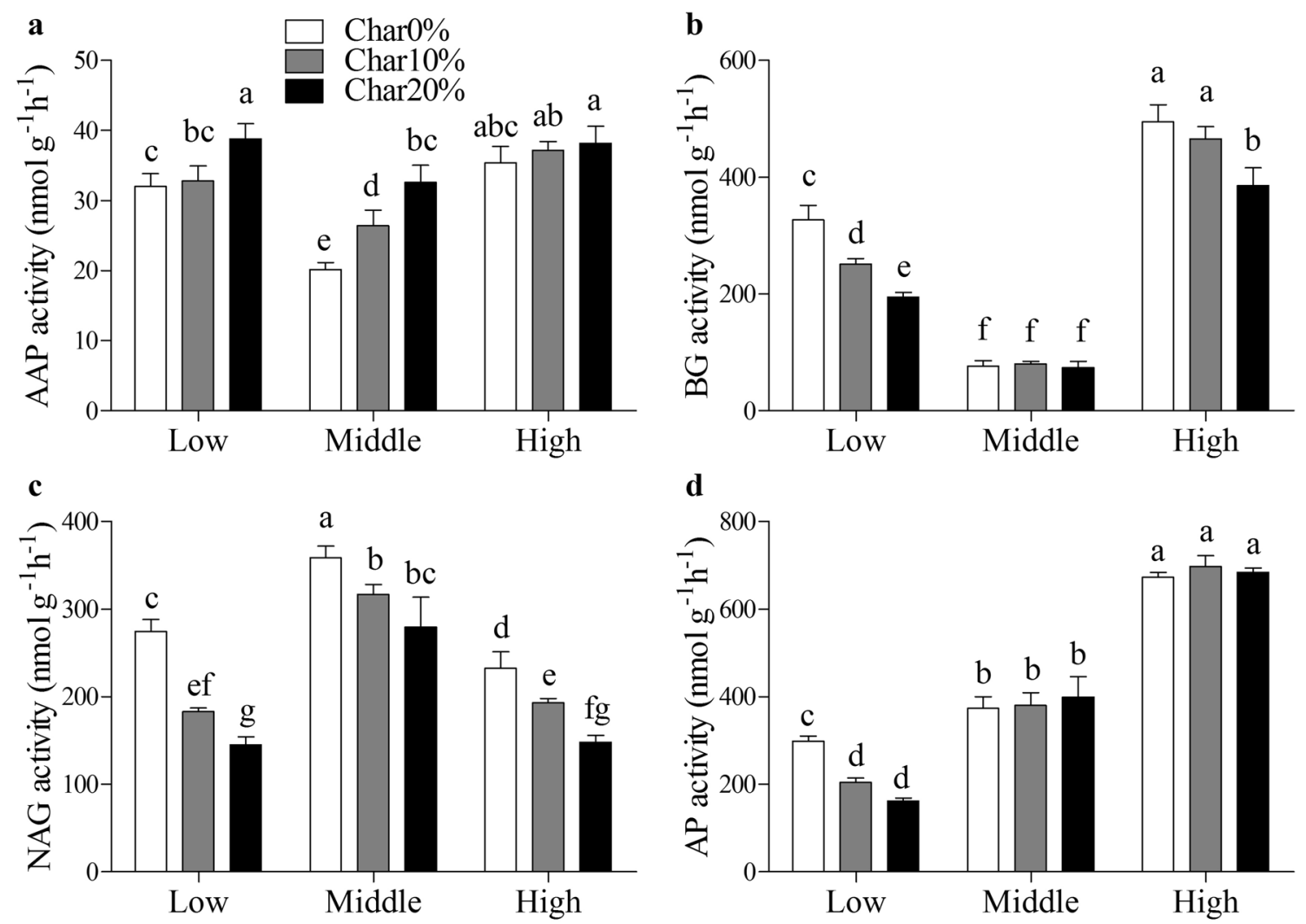

Fig. 3 Elevation and biochar effect on a alanine aminopeptidase (AAP), b $\beta$-glucosidase (BG), c $N$-acetyl- $\beta$-D-glucosaminidase (NAG) and $\mathbf{d}$ acid phosphatase (AP) activity. Different letters within each

frame indicate differences between treatments at the $P<0.05$ level. Low, middle and high represent three andic forest soils across an elevational gradient

construction. Compared to $\mathrm{N}$ enzymes, the $\mathrm{C}$ enzyme BG showed decreased activity with biochar addition. Biochar addition should have elevated short-term $C$ availability to soil microorganisms with the input of residue pyrolysis oil associated with char particles. This elevated $C$ availability could have suppressed microbial production of $C$ enzymes. The introduced residue oil should be rapidly assimilated and respired within a few days according to past studies $[66,72]$. However, biochar-induced low $C$ acquisition strategy within microorganisms seemed to persist after 3 months of incubation. We are unsure whether this is caused by microbial consumption of the inert $\mathrm{C}$ of biochar [73]. In general, responses in $\mathrm{N}$ and $\mathrm{C}$ enzymes seem to show higher microbial demand for amino acid $\mathrm{N}$ and lower demand for $\mathrm{C}$ after 3-month biochar incubation.

Biochar addition shows important impact on soil $\mathrm{N}$ cycling. Soils treated with biochar present smaller plantavailable $\mathrm{N}$ pools, but not lower total soil $\mathrm{N}$ (except a slight decrease in the $20 \%$ biochar-added high-elevation soils), even though incorporation of biochar could have introduced biochar-associated $\mathrm{NH}_{4}{ }^{+}$and $\mathrm{NO}_{3}{ }^{-}$into the soil. One explanation is that biochar has driven a higher fraction of soil $\mathrm{N}$ stored in soil organic matter. During the

initial stage of biochar incubation, microbial assimilation of the labile $C$ associated with biochar could have led to an increased immobilization of $\mathrm{N}$ into microbial biomass. Past studies have shown higher microbial biomass growth with biochar addition [74-76]. Nevertheless, the recycling speed of organic matter seems to be similar among soils with and without biochar after 3 months of incubation, with the turnover of small organic $\mathrm{N}$ not affect by biochar. Biochar did not affect the $\mathrm{N}$ mineralization potential, but decreased nitrification rate. The lower and negative nitrification rates suggest that biochar addition could decrease the risk of soil $\mathrm{N}$ losses through nitrate leaching processes.

Biochar's effects on soil properties have important implications for the soil microbial community structure and forest development under biochar application. Increased forest soil pH under biochar treatment could negatively impact fungal population and increase bacteria abundance [77], whereas increased microbial demand for $\mathrm{N}$ could induce fungal communities that are specifically efficient at $\mathrm{N}$ exploration in boreal forests [78]. Because biochar decreased soil soluble $\mathrm{N}$ availability for plants, a higher allocation to mycorrhizal association or selection of mycorrhizal partners with higher 


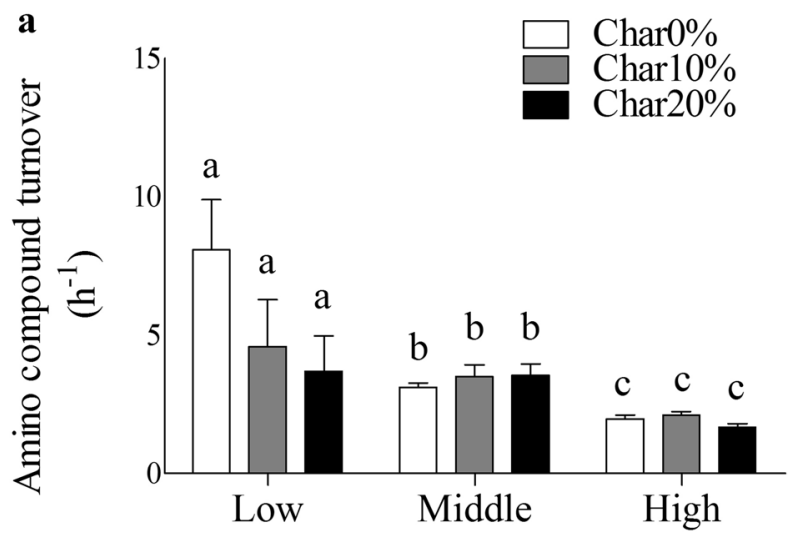

b

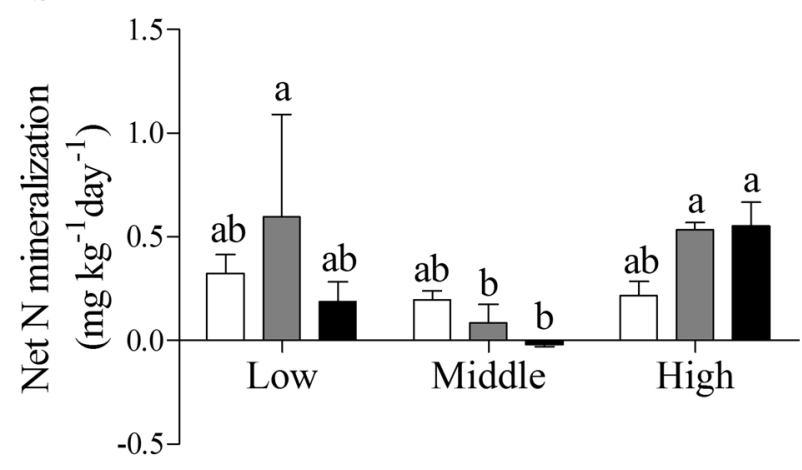

c

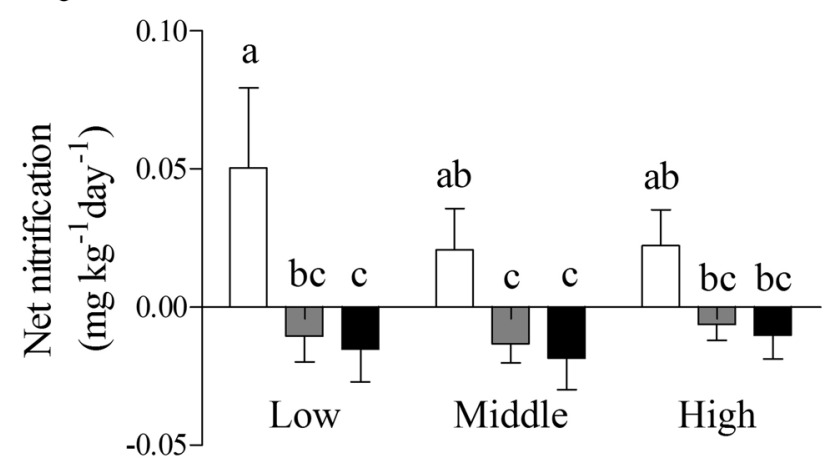

Fig. 4 Elevation and biochar effect on a soil amino compound turnover, $\mathbf{b}$ net $\mathrm{N}$ mineralization and $\mathbf{c}$ net nitrification rate after incubation. Different letters within each frame indicate differences between treatments at the $P<0.05$ level. Low, middle and high represent three andic forest soils across an elevational gradient

capability of $\mathrm{N}$ acquisition by plants could occur under biochar influence [79]. For instance, ectomycorrhizal fungi are well known in their role of releasing proteolytic enzymes and contributing to plant $\mathrm{N}$ uptake, whereas less evidence of this ability is reported for arbuscular mycorrhizal fungi $[80,81]$. It remains unknown whether ectomycorrhizal fungi-associated tree species would benefit from biochar application during competition with arbuscular mycorrhizal fungi-associated species or non-mycorrhizal species during forest succession.

\section{Conclusion}

This 3-month greenhouse incubation study shows that hardwood forest residue biochar addition in Andisols of north Idaho cold-temperate forest decreases the pool sizes of plant-available organic and inorganic N. Biochar addition affects soil microbial demand for $\mathrm{N}$ while suppressing their demand for $\mathrm{C}$. We concluded that shortterm incubation with hardwood forest residue biochar could result in negative impact on plant uptake of soil $\mathrm{N}$. However, for these forest stands which develop over decades and are always $\mathrm{N}$-limited, the dosage and long-term effect of biochar application still remain unknown and deserve more attention in future study.

Acknowledgements This research was funded by the US Forest Service, Rocky Mountain Research Station, Recovery Act Joint Venture Agreement No. 10-JV-112282B1-015 and McIntire-Stennis Cooperative Forestry Research Project No. IDAZ-MS-0099. Special thanks go to Debbie Page-Dumroese and Joanne Triocke at the US Forest Service, Rocky Mountain Research Station, Moscow, for their assistance in laboratory facility and techniques. We also would like to thank Anita Falen at the University of Idaho pedology laboratory for her assistance in nutrient analysis. More acknowledgements go to Intermountain Forest Tree Nutrient Cooperative colleagues for their consistent support.

\section{Compliance with ethical standards}

Conflict of interest The authors declare that they have no conflict of interest.

\section{References}

1. Westerling AL, Hidalgo HG, Cayan DR, Swetnam TW (2006) Warming and earlier spring increase western US forest wildfire activity. Science 313:940-943

2. Laird DA (2008) The charcoal vision: a win-win-win scenario for simultaneously producing bioenergy, permanently sequestering carbon, while improving soil and water quality. Agron J 100(1):178-181

3. Coleman M et al (2010) Can portable pyrolysis units make biomass utilization affordable while using bio-char to enhance soil productivity and sequester carbon. In: Jain TB, Graham RT, Sandquist J (eds) Integrated management of carbon sequestration and biomass utilization opportunities in a changing climate. Proceedings RMRS-P-61, pp 159-168

4. Lehmann J, Gaunt J, Rondon M (2006) Bio-char sequestration in terrestrial ecosystems-a review. Mitig Adapt Strat Glob Change $11: 395-419$

5. McElligott K, Dumroese D, Coleman M (2011) Bioenergy production systems and biochar application in forests: potential for renewable energy, soil enhancement, and carbon sequestration. Res Note RMRS-RN-46 
6. Woolf $D$, Amonette JE, Street-Perrott FA, Lehmann J, Joseph S (2010) Sustainable biochar to mitigate global climate change. Nat Commun 1:56

7. Page-Dumroese DS, Coleman MD, Thomas SC (2016) Opportunities and uses of biochar on forest sites in North America. In: Bruckman V, Varol EA, Uzun B, Liu J (eds) Biochar: a regional supply chain approach in view of mitigating climate change. Cambridge University Press, Cambridge, pp 315-336

8. Robertson SJ, Rutherford PM, López-Gutiérrez JC, Massicotte HB (2012) Biochar enhances seedling growth and alters root symbioses and properties of sub-boreal forest soils. Can J Soil Sci 92:329-340

9. Thomas SC, Gale N (2015) Biochar and forest restoration: a review and meta-analysis of tree growth responses. New For 46:931-946

10. Sarauer JL, Page-Dumroese DS, Coleman MD (2019) Soil greenhouse gas, carbon content, and tree growth response to biochar amendment in western United States forests. GCB Bioenergy 11:660-671

11. Gundale MJ, Nilsson M-C, Pluchon N, Wardle DA (2016) The effect of biochar management on soil and plant community properties in a boreal forest. GCB Bioenergy 8:777-789

12. Luo Y, Yu Z, Zhang K, Xu J, Brookes PC (2016) The properties and functions of biochars in forest ecosystems. J Soil Sediment 16:2005-2020

13. Compton JE, Church MR, Larned ST, Hogsett WE (2003) Nitrogen export from forested watersheds in the Oregon Coast Range: the role of $\mathrm{N}_{2}$-fixing red alder. Ecosystems 6:773-785

14. Van Miegroet $H$, Cole D (1984) The impact of nitrification on soil acidification and cation leaching in a red alder ecosystem 1. J Environ Qual 13:586-590

15. Schimel JP, Bennett J (2004) Nitrogen mineralization: challenges of a changing paradigm. Ecology 85:591-602

16. Jones DL, Kielland K (2002) Soil amino acid turnover dominates the nitrogen flux in permafrost-dominated taiga forest soils. Soil Biol Biochem 34:209-219

17. Inselsbacher E, Näsholm T (2012) The below-ground perspective of forest plants: soil provides mainly organic nitrogen for plants and mycorrhizal fungi. New Phytol 195:329-334

18. Inselsbacher E, Oyewole OA, Näsholm T (2014) Early season dynamics of soil nitrogen fluxes in fertilized and unfertilized boreal forests. Soil Biol Biochem 74:167-176

19. Shan S, Coleman M, Kimsey M (2014) Soil soluble nitrogen availability across an elevation gradient in a cold-temperate forest ecosystem. Soil Sci Soc Am J 78:S217-S224

20. Ball PN, MacKenzie MD, DeLuca TH, Montana WEH (2010) Wildfire and charcoal enhance nitrification and ammoniumoxidizing bacterial abundance in dry montane forest soils. J Environ Qual 39:1243-1253

21. DeLuca TH, Aplet GH (2008) Charcoal and carbon storage in forest soils of the Rocky Mountain West. Front Ecol Environ 6:18-24

22. Donato DC, Campbell JL, Fontaine JB, Law BE (2009) Quantifying char in postfire woody detritus inventories. Fire Ecol 5:104-115

23. Streubel JD, Collins HP, Garcia-Perez M, Tarara J, Granatstein D, Kruger CE (2011) Influence of contrasting biochar types on five soils at increasing rates of application. Soil Sci Soc Am J 75:1402-1413

24. Mukherjee A, Lal R (2014) The biochar dilemma. Soil Res $52: 217-230$

25. Clough TJ, Condron LM, Kammann C, Müller C (2013) A review of biochar and soil nitrogen dynamics. Agronomy 3:275-293

26. Zheng H, Wang Z, Deng $X$, Herbert $S$, Xing $B$ (2013) Impacts of adding biochar on nitrogen retention and bioavailability in agricultural soil. Geoderma 206:32-39
27. DeForest JL, Otuya RK (2020) Soil nitrification increases with elevated phosphorus or soil pH in an acidic mixed mesophytic deciduous forest. Soil Biol Biochem 142:107716

28. Teutscherova N, Vazquez E, Masaguer A, Navas M, Scow KM, Schmidt R, Benito M (2017) Comparison of lime- and biocharmediated $\mathrm{pH}$ changes in nitrification and ammonia oxidizers in degraded acid soil. Biol Fertil Soils 53:811-821

29. Karhu K, Seppänen A, Kitzler B, Tammeorg P, Kalu S, Virtanen E, Rasa K (2018) Potential of biochar soil amendments to reduce $\mathrm{N}$ leaching in boreal field conditions estimated using the resin bag method. In: EGU general assembly conference abstracts, $p$ 9830

30. De Graaff MA, Classen AT, Castro HF, Schadt CW (2010) Labile soil carbon inputs mediate the soil microbial community composition and plant residue decomposition rates. New Phytol 188:1055-1064

31. Laird DA, Brown RC, Amonette JE, Lehmann J (2009) Review of the pyrolysis platform for coproducing bio-oil and biochar. Biofuel Bioprod Biorefining 3:547-562

32. McCormack SA, Ostle N, Bardgett RD, Hopkins DW, Pereira MG, Vanbergen AJ (2019) Soil biota, carbon cycling and crop plant biomass responses to biochar in a temperate mesocosm experiment. Plant Soil 440:341-356

33. Mandal S, Thangarajan R, Bolan NS, Sarkar B, Khan N, Ok YS, Naidu R (2016) Biochar-induced concomitant decrease in ammonia volatilization and increase in nitrogen use efficiency by wheat. Chemosphere 142:120-127

34. Nelissen V, Rütting T, Huygens D, Ruysschaert G, Boeckx P (2015) Temporal evolution of biochar's impact on soil nitrogen processes-a ${ }^{15} \mathrm{~N}$ tracing study. GCB Bioenergy 7:635-645

35. Xu N, Tan G, Wang H, Gai X (2016) Effect of biochar additions to soil on nitrogen leaching, microbial biomass and bacterial community structure. Eur J Soil Biol 74:1-8

36. Castaldi S et al (2011) Impact of biochar application to a Mediterranean wheat crop on soil microbial activity and greenhouse gas fluxes. Chemosphere 85:1464-1471

37. Dempster DN, Gleeson DB, Solaiman ZM, Jones DL, Murphy DV (2012) Decreased soil microbial biomass and nitrogen mineralisation with Eucalyptus biochar addition to a coarse textured soil. Plant Soil 354:311-324

38. Gao S, DeLuca T (2016) Influence of biochar on soil nutrient transformations, nutrient leaching, and crop yield. Adv Plants Agric Res 4:1-16

39. Jones DL, Rousk J, Edwards-Jones G, DeLuca TH, Murphy DV (2012) Biochar-mediated changes in soil quality and plant growth in a three year field trial. Soil Biol Biochem 45:113-124

40. Awad YM, Blagodatskaya E, Ok YS, Kuzyakov Y (2012) Effects of polyacrylamide, biopolymer, and biochar on decomposition of soil organic matter and plant residues as determined by ${ }^{14} \mathrm{C}$ and enzyme activities. Eur J Soil Biol 48:1-10

41. Bailey VL, Fansler SJ, Smith JL, Bolton H (2011) Reconciling apparent variability in effects of biochar amendment on soil enzyme activities by assay optimization. Soil Biol Biochem 43:296-301

42. Elzobair KA, Stromberger ME, Ippolito JA (2016) Stabilizing effect of biochar on soil extracellular enzymes after a denaturing stress. Chemosphere 142:114-119

43. Niemi RM, Heiskanen I, Saarnio S (2015) Weak effects of biochar amendment on soil enzyme activities in mesocosms in bare or Phleum pratense soil. Boreal Environ Res 20:324-334

44. Wang X, Song D, Liang G, Zhang Q, Ai C, Zhou W (2015) Maize biochar addition rate influences soil enzyme activity and microbial community composition in a fluvo-aquic soil. Appl Soil Ecol 96:265-272

45. Smith D (2013) Biochar amendment alteration of forest soil extracellular enzyme activity and soil respiration in relation to 
fertilizer amendment and forest stand age. Natural Resources University of Idaho, Moscow, pp 1-8, 123

46. Gul S, Whalen JK, Thomas BW, Sachdeva V, Deng H (2015) Physico-chemical properties and microbial responses in biocharamended soils: mechanisms and future directions. Agric Ecosyst Environ 206:46-59

47. Pereira EIP, Suddick EC, Mansour I, Mukome FND, Parikh SJ, Scow K, Six J (2015) Biochar alters nitrogen transformations but has minimal effects on nitrous oxide emissions in an organically managed lettuce mesocosm. Biol Fertil Soils 51:573-582

48. Whitman T, Singh BP, Zimmerman AR, Lehmann J, Joseph S (2015) Priming effects in biochar-amended soils: implications of biochar-soil organic matter interactions for carbon storage. Biochar Environ Manag Sci Technol Implement 2:455-488

49. Zimmerman $A R$, Ouyang $L$ (2019) Priming of pyrogenic $C$ (biochar) mineralization by dissolved organic matter and vice versa. Soil Biol Biochem 130:105-112

50. Li Y et al (2018) Effects of biochar application in forest ecosystems on soil properties and greenhouse gas emissions: a review. J Soil Sediment 18:546-563

51. McDaniel P, Lowe D, Arnalds O, Ping C (2012) Andisols. In: Huang PM, Li Y, Sumner ME (eds) Handbook of soil sciences, properties and processes, vol 1. CRC Press, Boca Raton, pp 33.29-33.48

52. McDaniel PA, Fosberg MA, Falen AL (1993) Expression of andic and spodic properties in tephra-influenced soils of northern Idaho, USA. Geoderma 58:79-94

53. Staff SS (2012) Web soil survey. NRCS, Washington, DC. http:// websoilsurvey.nrcs.usda.gov/. Accessed 20 Nov 2012

54. Rehfeldt GE (2006) A spline model of climate for the western United States. In: Gen tech rep RMRS-GTR-165. US Department of Agriculture, Forest Service, Rocky Mountain Research Station, Fort Collins, p 165

55. Jones DL, Owen AG, Farrar JF (2002) Simple method to enable the high resolution determination of total free amino acids in soil solutions and soil extracts. Soil Biol Biochem 34:1893-1902

56. Saiya-Cork KR, Sinsabaugh RL, Zak DR (2002) The effects of long term nitrogen deposition on extracellular enzyme activity in an Acer saccharum forest soil. Soil Biol Biochem 34:1309

57. DeForest JL (2009) The influence of time, storage temperature, and substrate age on potential soil enzyme activity in acidic forest soils using MUB-linked substrates and I-DOPA. Soil Biol Biochem 41:1180-1186

58. Gardner B (2007) Field identification of andic soil properties for soils of north-central Idaho. In: Page-Dumroese D, Miller R, Mital J, McDaniel P, Miller D (eds) Volcanic-ash-derived forest soils of the inland northwest: properties and implications for management and restoration. Proceedings RMRS-P-44, pp 23-30

59. Gao S, DeLuca TH (2019) Use of microdialysis to assess shortterm soil soluble $\mathrm{N}$ dynamics with biochar additions. Soil Biol Biochem 136:107512

60. Brackin R et al (2016) Microdialysis-a new technology for investigating soil nitrogen fluxes in the rhizosphere. In: 7th international nitrogen initiative conference

61. Kimsey M, Gardner B, Busacca A (2007) Ecological and topographic features of volcanic ash-influenced forest soils. In: Volcanic-ash-derived forest soils of the Inland Northwest: properties and implications for management and restoration. Proceedings RMRS-P-44, pp 7-21

62. Weier KL, Doran JW, Power JF, Walters DT (1993) Denitrification and the dinitrogen/nitrous oxide ratio as affected by soil water, available carbon, and nitrate. Soil Sci Soc Am J 57:66-72
63. Prendergast-Miller MT, Duvall M, Sohi SP (2011) Localisation of nitrate in the rhizosphere of biochar-amended soils. Soil Biol Biochem 43:2243-2246

64. Biederman LA, Harpole WS (2013) Biochar and its effects on plant productivity and nutrient cycling: a meta-analysis. GCB Bioenergy 5:202-214

65. Prommer J et al (2014) Biochar decelerates soil organic nitrogen cycling but stimulates soil nitrification in a temperate arable field trial. PLoS ONE 9:e86388

66. Novak JM, Busscher WJ, Watts DW, Laird DA, Ahmedna MA, Niandou MAS (2010) Short-term $\mathrm{CO}_{2}$ mineralization after additions of biochar and switchgrass to a Typic Kandiudult. Geoderma 154:281-288

67. Liu Q et al (2018) How does biochar influence soil N cycle? A meta-analysis. Plant Soil 426:211-225

68. Omondi MO, Xia X, Nahayo A, Liu X, Korai PK, Pan G (2016) Quantification of biochar effects on soil hydrological properties using meta-analysis of literature data. Geoderma 274:28-34

69. Nguyen TTN et al (2017) Effects of biochar on soil available inorganic nitrogen: a review and meta-analysis. Geoderma 288:79-96

70. Niemi RM, Vepsäläinen M (2005) Stability of the fluorogenic enzyme substrates and $\mathrm{pH}$ optima of enzyme activities in different Finnish soils. J Microbiol Methods 60:195-205

71. Moye ZD, Burne RA, Zeng L (2014) Uptake and metabolism of $\mathrm{N}$-acetylglucosamine and glucosamine by Streptococcus mutans. Appl Environ Microbiol 80:5053-5067

72. Farrell $M$ et al (2013) Microbial utilisation of biochar-derived carbon. Sci Total Environ 465:288-297

73. Zavalloni C, Alberti G, Biasiol S, Delle Vedove G, Fornasier F, Liu J, Peressotti A (2011) Microbial mineralization of biochar and wheat straw mixture in soil: a short-term study. Appl Soil Ecol 50:45-51

74. Shuwei $L$ et al (2016) Response of soil carbon dioxide fluxes, soil organic carbon and microbial biomass carbon to biochar amendment: a meta-analysis. GCB Bioenergy 8:392-406

75. Song Y, Zhang X, Ma B, Chang SX, Gong J (2014) Biochar addition affected the dynamics of ammonia oxidizers and nitrification in microcosms of a coastal alkaline soil. Biol Fertil Soils 50:321-332

76. Palviainen $\mathrm{M}$ et al (2018) Effects of biochar on carbon and nitrogen fluxes in boreal forest soil. Plant Soil 425:1-15

77. Högberg MN, Högberg P, Myrold DD (2007) Is microbial community composition in boreal forest soils determined by $\mathrm{pH}$, C-to-N ratio, the trees, or all three? Oecologia 150:590-601

78. Allison SD, LeBauer DS, Ofrecio MR, Reyes R, Ta A-M, Tran TM (2009) Low levels of nitrogen addition stimulate decomposition by boreal forest fungi. Soil Biol Biochem 41:293-302

79. Kiers ET et al (2011) Reciprocal rewards stabilize cooperation in the mycorrhizal symbiosis. Science 333:880-882

80. Correa A, Cruz C, Ferrol N (2015) Nitrogen and carbon/nitrogen dynamics in arbuscular mycorrhiza: the great unknown. Mycorrhiza 25:499-515

81. Smith SE, Read DJ (2010) Mycorrhizal symbiosis. Academic Press, Cambridge

Publisher's Note Springer Nature remains neutral with regard to jurisdictional claims in published maps and institutional affiliations. 